\title{
PENGARUH KINERJA KEUANGAN, RISK BASED CAPITAL, UKURAN PERUSAHAAN DAN MAKROEKONOMI TERHADAP FINANCIAL DISTRESS
}

\author{
Agustina Nilasari ${ }^{1}$ \\ STIE Surakarta, Indonesia \\ Ismunawan \\ STIE Surakarta, Indonesia
}

\begin{abstract}
This research intends to examine the effect of insurance company financial ratios, namely solvency margin ratio, risk based capital, firm size, inflation and exchange rate on the estimated financial distress of life insurance companies. As well as general public listed on the Indonesia Stock Exchange from 2015 to 2019. This research is important considering that there have been cases of default by insurance companies. The research information in this research is secondary data obtained in the annual report which is sourced from BEI website and insurance company websites. The sample technique in this research is a purposive sampling technique, there are 35 samples that meet the standards to become samples. Insurance companies experiencing financial distress are determined based on the non-manufacturing Altman Z-score method. Multiple linear regression is the research technique chosen by researchers. This research results in the conclusion that only the firm size variable has an influence on financial distress estimates. The independent variables are able to explain the financial distress variable as much as $32.8 \%$, the deficiency as much as $67.2 \%$, which illustrates the variables that cannot be taken into account in the analysis of this study.
\end{abstract}

JEL : G22, G33, G52

Keywords : financial distress, risk based capital, macroeconomics, altman z-score.

\begin{abstract}
ABSTRAK
Riset ini bermaksud untuk menelaah pengaruh rasio keuangan perusahaan asuransi yakni solvency margin ratio (SMR), risk based capital (RBC), ukuran perusahaan (UK), inflasi (INF) serta nilai tukar (NT) terhadap perkiraan timbulnya keadaan financial distress perusahaan asuransi jiwa serta umum yang tercatat pada Bursa Efek Indonesia dari rentang waktu 2015 sampai 2019. Penelitian ini penting mengingat adanya kasus gagal bayar perusahaan asuransi. Informasi penelitian di dalam riset ini merupakan data sekunder yang didapatkan pada annual report yang bersumber dari website BEI serta website perusahaan asuransi. Teknik sampel di dalam riset ini merupakan teknik purposive sampling, terdapat 35 sampel yang memenuhi standar untuk menjadi sampel. Perusahaan asuransi yang mengalami financial distress ditentukan berdasarkan metode Altman Z-score non manufaktur. Regresi linier berganda menjadi teknik penelitian yang dipilih oleh peneliti. Riset ini menghasilkan kesimpulan bahwa hanya variabel ukuran perusahaan (UK) yang ada pengaruh terhadap perkiraan financial distress. Variabel bebas mampu memaparkan variabel financial distress sebanyak 32,8\%, kekurangan sebanyak $67,2 \%$ digambarkan variabel yang tidak dapat diperhitungkan di dalam analisis penelitian ini.
\end{abstract}

Kata Kunci : financial distress, makroekonomi, altman z-score.

\section{PENDAHULUAN}

Di Indonesia perkembangan perusahaan asuransi tergolong masih lamban daripada sektor perbankan. Otoritas Jasa Keuangan (OJK) mengatakan pada era 2018, jumlah pendapatan premi

\footnotetext{
${ }^{1}$ Email : agustinanilasari@gmail.com

Received : 06-02-2021, Accepted: 24-04-2021, Published : 29-04-2021

P-ISSN : 2087-9954, E-ISSN : 2550-0066. DOI : http://dx.doi.org/10.26418/jebik.v10i1.44793
} 
yang diperoleh perusahaan asuransi hanya sebesar 9\%. Sedangkan, pertumbuhan penyaluran kredit yang diperolah perbankan sebesar $12,88 \%$. Keadaan tersebut terjadi karena masyarakat mengalami krisis kepercayaan terhadap perusahaan asuransi akibat dari mencuatnya kasus gagal bayar perusahaan asuransi sebagaimana yang terjadi pada PT Asuransi Jiwasraya (Ananta, 2019). Gagal bayar yaitu kondisi dimana PT Asuransi Jiwasraya tidak dapat memenuhi kewajiban kepada nasabahnya. Tingginya kewajiban yang harus dibayar kepada nasabah tidak sebanding dengan nilai aset yang dimiliki PT Asuransi Jiwasraya, keadaan tersebut akan membuat perusahaan mengalami financial distress yang tidak menutup kemungkinan akan menjurus ke arah kebangkrutan (Trivena, Wijayanti, \& Budiarti, 2020).

Faktor perusahaan mengalami financial distress dikategorikan menjadi dua, yaitu faktor internal yang berupa kesalahan manajemen perusahaan, penyalahgunaan wewenang, keseimbangan dalam modal dan kecurangan-kecurangan dalam pelaporan laporan keuangan yang dapat menyebabkan kebangkrutan. Sedangkan faktor eksternal berupa bencana alam, kondisi makro ekonomi dan kondisi geografis. Kondisi makro ekonomi dapat berupa rendahnya kurs rupiah atas dolar AS, suku bunga serta inflasi. Analisis laporan keuangan harus dilakukan perusahaan sebagai upaya untuk menghindari kemungkinan financial distress (Ramadhani \& Lukviarman, 2009).

Menurunnya kurs rupiah yang sampai menjangkau digit Rp 14.000 di tahun 2018 yang dikarenakan perang dagang diantara Amerika Serikat serta china menjadi sebuah ancaman bagi perusahaan yang beroperasi di Indonesia. Pergerakan nilai tukar yang tidak menentu menunjukan bahwa ketidakstabilan perekonomian suatu negara. Kurs yang cenderung tidak menentu akan berpengaruh pada permintaan saham serta akan mempengaruhi return saham. Saat keadaan kurs naik maka harga saham cenderung mengalami penurunan diikuti oleh penurunan return saham (Muatthoroh, 2019). Apabila nilai tukar rupiah tidak kunjung menguat, maka tidak menutup kemungkinan perusahaan yang beroperasi di Indonesia terancam menghadapi financial distress. Perusahaan asuransi menjadi satu dari beberapa perusahaan yang mengecap efek lesunya kurs rupiah atas dolar AS, sehingga menunjukan gejala financial distress.

Kondisi finansial dan juga kinerja finansial perusahaan pada kurun waktu tertentu tercermin dalam financial statements yang menjadi sumber informasi penting bagi pihak yang membutuhkan. Kinerja keuangan bisa menjadi tolok ukur keuangan perusahaan dalam kondisi sehat atau buruk yang menunjukkan potensi financial distress sebelum nantinya terjadi kebangkrutan. Perusahaan asuransi mempunyai metode tersendiri untuk mengukur tingkat kesehatan dan performa keuangan perusahaan asuransi yang telah disusun The National Association Insurance Commisioners (NAIC). NAIC merupakan institusi pengawal perusahaan asuransi yang berada pada Amerika Serikat.

Dalam penelitian yang dilaksanakan oleh Zamachsyari \& Amanah (2016) menyimpulkan bahwa solvency margin ratio, rasio beban klaim dan rasio pertumbuhan premi, rasio likuiditas, return on assets serta ukuran berpengaruh secara negatif atas kemungkinan terjadinya financial distress. Serta penelitian yang dilaksanakan oleh Priyatnasari \& Hartono (2019) yang meneliti tentang rasio keuangan, makroekonomi serta financial distress (studi atas perusahaan perdagangan, jasa serta investasi) menyimpulkan bahwa rasio keuangan saja yang yang memiliki pengaruh atas financial distress. Kesimpulan tersebut bertentangan dengan penelitian yang dilaksanakan Rohiman \& Damayanti (2019) yang menyimpulkan inflasi dan nilai tukar memiliki pengaruh atas financial distress. 
Berdasarkan penelitian yang dilakukan sebelumnya, peneliti bermaksud untuk menguji kembali apakah hasil riset sebelumnya masih relevan dengan kondisi perekonomian indonesia saat ini. Sehingga peneliti bermaksud untuk meneliti Pengaruh Kinerja Keuangan, Risk Based Capital, Ukuran Perusahaan serta Makroekonomi terhadap Situasi Financial Distress (Analisis pada Perusahaan Asuransi yang Tercatat dalam BEI). Temuan di dalam penelitian ini diharapkan dapat membatu nasabah untuk memperkirakan faktor-faktor apa saja yeng mendorong perusahaan asuransi mengalami kondisi financial distress sehingga dapat memilih asuransi yang tepat demi proteksi di masa mendatang. Sedangkan untuk perusahaan, diharapkan dapat memberikan kontribusi informasi mengenai aspek-aspek yang mendorong timbulnya financial distress, sehingga perusahaan dapat lebih memperhatikan faktor yang mempengaruhi financial distress agar perusahaan dapat berjalan dalam jarak waktu yang tidak terbatas.

\section{KAJIAN LITERATUR}

\subsection{Financial Distress}

Menurut Fatmawati \& Wahidahwati (2017) dampak dari financial distress tidak hanya dirasakan oleh perusahaan saja, melainkan stakeholder dan shareholder juga akan terkena dampaknya. Kemungkinan financial distress mampu berlangsung di semua tipe perusahaan. Financial distress menjadi salah satu indikasi perusahaan akan mengalami kebangkrutan. Penyebab kebangkrutan bersumber dari luar ataupun dalam perusahaan. Aspek di dalam perusahaan seperti: kesalahan manajemen, tingginya jumlah hutang serta kerugian operasi perusahaan, sebaliknya aspek di luar perusahaan seperti kenaikan suku bunga (Fatmawati \& Wahidahwati, 2017). Ciri-ciri adanya ketidakberesan dari dalam perusahaan salah satunya yaitu adanya depresiasi kondisi keuangan yang lambat laun akan berakhir financial distress dan jika perusahaan tidak segera menangani masalah tersebut, kemudian tidak menutup peluang perusahaan akan mengalami kebangkrutan semakin besar (Dewi \& Mahfudz, 2017).

Financial distress dapat dinilai dengan berbagai macam cara dan model, salah satunya dapat menggunakan analisis laporan keuangan. Primasari (2018) menyampaikan tentang beberapa model peramalan financial distress diantaranya yakni The Springate, The Altman Model, Zmijewski Model, dan Grover Score. Berdasarkan penelitian yang dilakukan, The Altman Model menjadi salah satu model prediksi financial distress terbaik dengan nilai ketepatan sebesar 92,24\%. Altman Z-score dapat dimanfaatkan bagi pihak manajemen untuk melaksanakan maintain atas value of the firm yang berasal dari kesanggupan perusahaan mendapatkan profit serta memprediksi risiko financial perusahaan. Maka dari itu di dalam penelitian ini, model yang dimanfaatkan untuk memperkirakan financial distress yakni versi Altman Z-score bagi perusahaan non-manufaktur, dengan rumus:

$\mathrm{Z}=6,56 \mathrm{~T}^{1}+3,26 \mathrm{~T}^{2}+6,72 \mathrm{~T}^{3}+1,05 \mathrm{~T}^{4}$

Keterangan:

$Z$ = bankruptcy index,

$T^{1}=$ working capital/total assets,

$T^{2}=$ retained earnings/total assets,

$T^{3}=$ earnings before interest and taxes/total assets,

$T^{4}=$ market value of equity/total liabilities. 
Sedangkan zona deskriminasinya:

Apabila $\mathrm{Z}>2,9$ lalu dapat disimpulkan bahwa perusahaan ada pada zona "aman".

Apabila $1,22<\mathrm{Z}<2,9$ lalu dapat disimpulkan bahwa perusahaan berada dalam zona "abu-abu".

Apabila $\mathrm{Z}<2,99$ lalu dapat disimpulkan bahwa perusahaan berada dalam zona "distress".

\subsection{Kinerja Keuangan}

Perusahaan yang telah menjalankan usaha formal pada periode tertentu akan menghasilkan suatu posisi keuangan yang disebut kinerja keuangan (Nurfadila, Hidayat, \& Sulasmiyati, 2015). Data yang terkandung di dalam laporan keuangan dapat menggambarkan performa suatu perusahaan. Hasil dari sebuah alur pelaporan keuangan yang telah diatur oleh peraturan dan standar akuntansi disebut laporan keuangan (Subramanyam, 2017). Analisis rasio keuangan menjadi satu dari beberapa teknik yang bisa digunakan untuk mengerti bagaimana kinerja suatu perusahaan. Nurfadila et al., (2015) berpendapat bahwa suatu proses penyampaian informasi, penafsiran, penghitungan serta pengawasan data keuangan perusahaan pada kurun waktu tertentu disebut analisis laporan keuangan. Analisis rasio keuangan yang diberlakukan di perseroan bergantung pada jenis usaha yang dijalankan. Salah satu contoh adalah perusahaan asuransi, perusahaan asuransi mempunyai rumus tersendiri dalam menganalisis rasio keuangan. Early warning system yang dibentuk The National Association of Insurance Commisioners (NAIC) merupakan salah satu analisis yang dikenal untuk menganalisis rasio keuangan industri asuransi. Di negara Indonesia rasio early warning system yang diterapkan telah diatur pada Pernyataan Standar Akuntansi Keuangan (PSAK). PSAK tersebut ialah PSAK No 28 mengenai akuntansi asuransi kerugian.

\subsection{Solvency Margin Ratio}

Solvency margin solvency yaitu rasio yang difungsikan untuk memperkirakan tingginya kecakapan perusahaan dalam menanggung tanggungjawab yang muncul dari risiko yang telah ditutup (Afif \& Karmila, 2016). Sedangkan Zamachsyari \& Amanah (2016) berpendapat bahwa rasio margin solvency dapat diperuntukan dalam pengukuran tingkat solvabilitas perusahaan asuransi. Wiguna \& Susilawati (2020) menerangkan bahwa rasio margin solvensi ini menggambarkan seberapa tinggi kecakapan perusahaan dalam mengampu beban hutang. Rasio margin solvensi mempunyai batas minimal sebesar 33,3\%, jika perusahaan asuransi memiliki rasio margin solvensi diatas 33,3\% artinya perusahaan dalam keadaan baik. Semakin besar rasio margin solvensi lalu semakin baik kecakapan perusahaan dalam mengampu beban hutang.

\subsection{Risk Based Capital}

Penilaian performa perusahaan asuransi bukan hanya menerapkan analisis rasio keuangan saja, akan tetapi risk based capital dapat juga menjadi metode untuk mengukur kinerja perusahaan (Nurfadila et al., 2015). Risk based capital ialah rasio yang digunakan untuk menilai modal yang memadai terhadap risiko yang dipikul serta sebagai salah satu parameter dalam mentaksirkan kesehatan perusahaan asuransi, khusunya tentang kecakapan perusahaan asuransi dalam mencukupi semua kewajibannya (Utami \& Khoiruddin, 2016). Wiguna \& Susilawati (2020) mengatakan bahwa kualitas kesehatan perusahaan asuransi ataupun reasuransi dapat diukur menggunakan risk based capital. Risk based capital mempunyai nilai minimum sebesar $120 \%$, apabila perusahaan asuransi mempunyai risk based capital lebih tinggi dari $120 \%$ artinya perusahaan dalam keadaan baik. 


\subsection{Ukuran Perusahaan}

Ukuran perusahaan mendeskripsikan tentang kemampuan perusahaan untuk memikul risiko (Dewi \& Mahfudz, 2017). Besar kecilnya ukuran perusahaan asuransi menunjukan solven atau tidaknya perusahaan tersebut. Sedangkan Cinantya \& Merkusiwati (2015) berpendapat bahwa keseluruhan aset yang dikusai perusahaan menggambarkan betapa besarnya ukuran suatu perusahaan. Modal yang dialokasikan dari pinjaman untuk membelanjai semua aset pada perusahaan berukuran besar akan lebih berani daripada perusahaan berukuran kecil.

\subsection{Makroekonomi}

Makroekonomi yaitu ilmu ekonomi yang secara keseluruhan mendeskripsikan tentang peralihan ekonomi yang berdampak ke masyarakat luas, perusahaan serta pasar. Situasi makro suatu negara mampu memperkirakan keadaan financial distress suatu perusahaan, situasi makro di suatu negara yang buruk mempunyai peluang perusahaan yang beroperasi di negara tersebut menghadapi financial distress (Rohiman \& Damayanti, 2019). Perusahaan dituntut untuk peka terhadap kondisi makro ekonomi di negara yang menjadi tempat operasional perusahaan karena krisis ekonomi bisa kapan saja terjadi dan akan mengakibatkan perusahaan mengalami financial distress (Muatthoroh, 2019). Nilai tukar dan inflasi menjadi ukuran dalam variabel makroekonomi ini.

Inflasi menjadi masalah ekonomi makro yang dapat menyebabkan penurunan daya beli masyarakat. Suatu negara yang sedang menghadapi kondisi inflasi akan menghadapi keadaan dimana harga barang akan cenderung naik sedangkan nilai uang akan semakin turun. Darmawan (2017) berpendapat bahwa kenaikan harga suatu barang yang berkepanjangan akan menjadi sebuah peristiwa moneter yang biasa disebut inflasi. Muatthoroh (2019) mendefinisikan suatu situasi saat harga-harga barang mengalami peningkatan yang disebabkan oleh kejadian moneter disuatu negara disebut inflasi, kenaikan harga barang yang berkelanjutan akan memacu merangkaknya nilai inflasi di suatu negara.

Kurs adalah suatu harga dari nilai uang nasional dalam nilai uang negara luar (Darmawan, 2017). Sedangkan Muatthoroh (2019) berpendapat bahwa kurs ialah harga suatu pergerakan nilai tukar harga. Rohiman \& Damayanti (2019) berpendapat bahwa kurs merupakan nilai uang dari negara lain yang menyatakan besarnya harga atau nilai uang di suatu negara. Jika nilai tukar nasional lebih kecil daripada dolar AS, maka kondisi rupiah sedang menghadapi penurunan seperti itu akan berakibat pada peningkatan jumlah kewajiban yang harus dibayar (Rohiman \& Damayanti, 2019).

\subsection{Hubungan Antar variabel}

Rasio margin solvensi yaitu rasio yang mendeskripsikan tentang kecakapan perusahaan dalam menyelesaikan kewajiban yang akan muncul dari penutupan risiko yang akan timbul (Zamachsyari \& Amanah, 2016). Hasil dari perhitungan rasio ini dapat menunjukan kemampuan keuangan perusahaan asuransi dalam mendukung risiko yang mungkin timbul dari pertanggungan asuransi (Fatkurrohmah, Sukarno, \& Farida, 2015). Sehingga, semakin banyak risiko yang dihadapi perusahaan bakal menyebabkan tingginya probabilitas perusahaan mengalami financial distress (Zamachsyari \& Amanah, 2016). Perihal tersebut selaras pada hasil penelitian yang dilaksanakan Zamachsyari \& Amanah (2016) yang menegaskan bahwasanya rasio margin solvensi 
mempunyai pengaruh yang negatif akan kemungkinan financial distress. Berdasarkan kajian ini, maka hipotesis dari penelitian ini yaitu:

Hipotesis 1: Rasio margin solvensi mempunyai pengaruh yang negatif terhadap kemungkinan financial distress.

Risk based capital digunakan sebagai acuan untuk nasabah dalam menilai apakah perusahaan mempunyai kecukupan modal perusahaan jika nasabah tersebut ingin membeli polis (Nurfadila et al., 2015). Risk based capital setiap perusahaan asuransi harus mengantongi nilai minimal sebesar 120\% (Nurfadila et al., 2015). Jika perusahaan memiliki risk based capital lebih dari $120 \%$ maka dapat dipastikan perusahaan mampu menanggung risiko yang bisa terjadi di masa depan dengan sangat baik (Nurfadila et al., 2015). Hal tersebut berarti jika perusahaan memiliki risk based capital dibawah $120 \%$ maka perusahaan akan mengalami kesulitan dalam menanggung risiko, kesulitan tersebut akan memperbesar probabilitas perusahaan menghadapi financial distress. Berdasarkan penelitian yang dilaksanakan Dewi \& Mahfudz (2017) menunjukan bahwa risiko berbasis modal mempunyai hubungan positif terhadap financial distress. Sehingga, peneliti mengutarakan hipotesis sebagai berikut :

Hipotesis 2: Risk based capital mempunyai pengaruh positif terhadap kemungkinan financial distress.

Ukuran perusahaan bisa diartikan sebagai ukuran makro atau mikronya suatu perusahaan yang dapat dihitung berdasarkan keseluruhan aktiva yang dikuasai oleh perusahaan (Darmawan, 2017). Pertambahan aset yang positif dalam perusahaan dapat bermakna bahwa perusahaan tersebut terus berkembang dan memangkas probabilitas perusahaan menemui situasi financial distress. Pendapat tersebut selaras dengan hasil penelitian yang dilaksanakan Rahmawati \& Khoiruddin (2017) yang menunjukkan ukuran perusahaan ada pengaruh positif akan kondisi financial distress. Hingga, peneliti mengutarakan hipotesis:

Hipotesis 3: Ukuran perusahaan berhubungan positif terhadap kemungkinan financial distress.

Inflasi yaitu keadaan dimana harga barang akan naik secara keseluruhan (Darmawan, 2017). Kenaikan harga barang secara keseluruhan akan menurunkan permintaan konsumen akan suatu barang atau jasa sehingga pendapatan perusahan otomatis akan mengalami penurunan (Priyatnasari \& Hartono, 2019). Hal tersebut searah dengan Sepang, Johnson, \& Sihombing (2015) yang mengatakan tingginya inflasi dapat memberikan dampak negatif bagi perusahaan berupa penurunan pendapatan. Serta Muatthoroh (2019) berpendapat bahwa kenaikan harga yang disebabkan oleh inflasi menyebabkan turunnya daya beli masyarakat, hal tersebut juga membawa dampak pada permintaan akan saham yang ikut menurun sehingga akan menyebabkan penurunan harga saham serta return saham. Jika keadaan tersebut terjadi dalam kurun waktu yang lama, maka pendapatan perusahaan akan semakin berkurang sehingga akan memperbesar kemungkinan perusahaan akan menemui situasi financial distress (Darmawan, 2017). Permasalahan tersebut selaras dengan penelitian yang dilaksanakan oleh Ruhadi \& Mai (2017) serta Rohiman \& Damayanti (2019) yang berpendapat bahwa tingkat inflasi dapat memiliki pengaruh terhadap financial distress. Oleh sebab itu, peneliti mengajukan hipotesis sebagi berikut:

Hipotesis 4: Inflasi berpengaruh positif terhadap kemungkinan financial distress.

Tingkat kestabilan kurs dapat menunjukan stabilitas perekonomian suatu negara. Maka dari itu transformasi nilai tukar akan mempengaruhi permintaan saham serta return saham. Jika 
kurs mengalami kenaikan maka harga saham akan semakin turun disusul dengan return saham yang juga mengalami penurunan (Muatthoroh, 2019). Keadaan seperti itu akan mempengaruhi perusahaan asuransi dalam mendapat suntikan dana dari investor dan return saham. Perusahaan asuransi ialah lembaga keuangan non bank yang mengumpulkan kas berupa premi yang berasal dari publik. Apabila perusahaan menempatkan premi menjadi sumber penghasilan utama, belum pasti perusahaan tersebut dapat mencukupi kewajiban dalam menanggung risiko dan kondisi kesehatan perusahaan. Oleh karena itu, pendapatan premi harus dialokasikan kedalam investasi yang bersifat liquid, aman dan menguntungkan atau dengan melakukan go public (Rachmatin \& Negara, 2017). Oleh karena itu, jika kurs meningkat maka return saham dari aktivitas investasi perusahaan asuransi akan mengalami penurunan serta permintaan saham akan mengalami penurunan. Kondisi seperti itu akan memperbesar probabilitas perusahaan menghadapi financial distress. Keadaan tersebut selaras dengan penelitian yang dilaksanakan Rohiman \& Damayanti (2019) yang menegaskan bahwa nilai tukar memiliki pengaruh terhadap financial distress. Maka dari itu, peneliti mengajukan hipotesis:

Hipotesis 5: Nilai tukar berpengaruh positif terhadap kemungkinan financial distress.

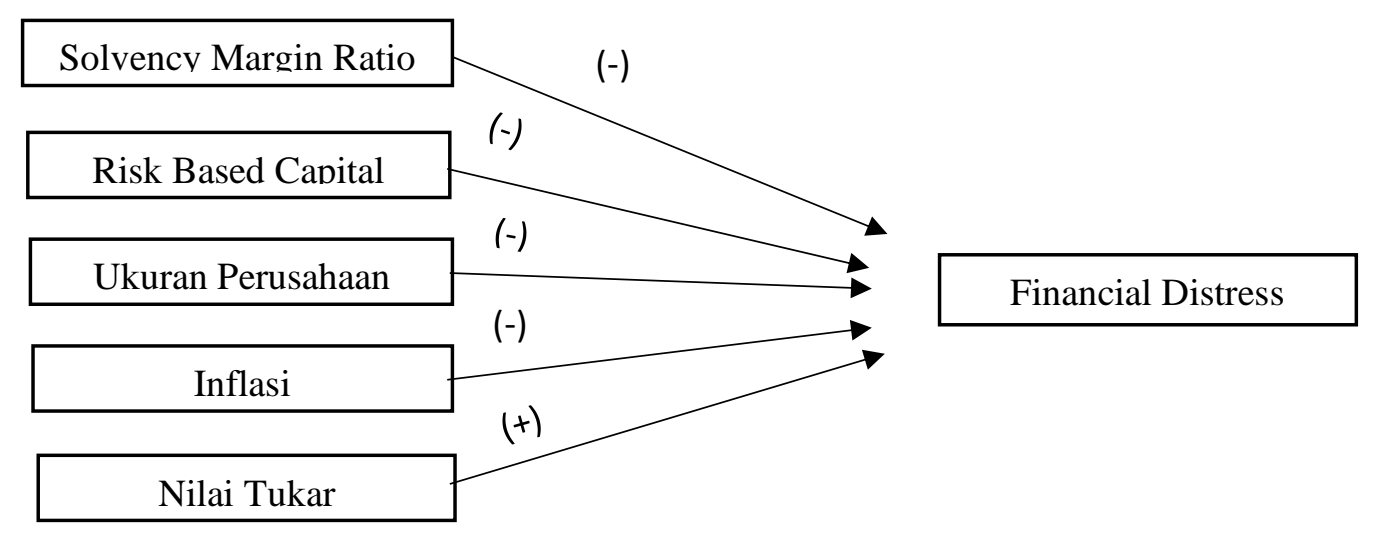

Gambar 1. Kerangka Penelitian

\section{METODE PENELITIAN}

Tipe penelitian yang telah ditetapkan di dalam riset ini yakni penelitian kuantitatif. Penelitian kuantitatif ialah penelitian yang memprioritaskan pada kegiatan percobaan hipotesa beserta pengaplikasian metode yang akan melahirkan sebuah kesimpulan. Kemudian, penelitian ini juga menggunakan penelitian kausal-komperatif yaitu model penelitian yang meneliti tentang kausalitas dari suatu insiden dalam objek penelitian tertentu. Sementara itu, objek yang ditetapkan dalam penelitian merupakan perusahaan asuransi jiwa dan umum yang terdaftar dalam Bursa Efek Indonesia (BEI).

Metode pengambilan sampel yang telah ditetapkan di dalam penelitian ialah purposive sampling yaitu suatu metode pengambilan sampel yang menggunakan kriteria tertentu. Penggunaan kriteria dalam penelitian ini yaitu perusahaan asuransi jiwa dan umum yang secara teratur menerbitkan laporan keuangan pada tahun 2015-2019 serta menyediakan data lengkap yang berkaitan dengan perhitungan rasio variabel penelitian dan tidak memiliki status likuidasi atas kegiatan usahanya pada tahun 2015-2019. Perusahaan yang termuat di dalam Bursa Efek Indonesia 
yaitu sebesar 14 perusahaan. Sampel yang memenuhi kriteria seperti yang sudah dijelaskan adalah sebanyak 7 perusahaan dikalikan dengan periode penelitian yaitu sebanyak 35 perusahaan.

Metode pengumpulan data di dalam penelitian dilaksanakan memakai cara peneliti melakukan analisis pada seluruh dokumen dan catatan laporan keuangan yang dimiliki perusahaan, metode tersebut disebut sebagai teknik dokumentasi. Sumber data penelitian ini dimuat dalam laporan keuangan yang telah dipublikasi Bursa Efek Indonesia. Selain itu, data indeks harga konsumen dan tahap inflasi yang telah diterbitkan oleh Bank Indonesia dan Badan Pusat Statistik.

Variabel terikat yang ditetapkan di dalam penelitian yakni financial distress. Variabel financial distress di dalam penelitian ini dinilai menggunakan versi Altman Z-score bagi perusahaan non-manufaktur, dengan rumus:

$\mathrm{Z}=6,56 \mathrm{~T}^{1}+3,26 \mathrm{~T}^{2}+6,72 \mathrm{~T}^{3}+1,05 \mathrm{~T}^{4}$

Keterangan:

$Z$ = bankruptcy index,

$T^{l}=$ working capital/total assets,

$T^{2}=$ retained earnings/total assets,

$T^{3}=$ earnings before interest and taxes/total assets,

$T^{4}=$ market value of equity/total liabilities

Sedangkan zona deskriminasinya yaitu:

Jika $Z>2,9$ lalu dapat disimpulkan bahwa perusahaan berada dalam zona "aman".

Jika 1,22<Z<2,9 lalu dapat disimpulkan bahwa perusahaan berada dalam zona "abu-abu".

Jika $\mathrm{Z}<2,99$ lalu dapat disimpulkan bahwa perusahaan berada dalam zona "distress".

Variabel bebas yang ditetapkan di dalam penelitian mencakup lima variabel meliputi solvency margin ratio, risk based capital, ukuran perusahaan, inflasi dan nilai tukar. Gambaran dan pengukuran mengenai masing-masing variabel dijelaskan dalam Tabel 1. Metode analisis data yang difungsikan di dalam penelitian merupakan teknik analisis statistik deskriptif serta statistik inferensial yang akan didukung oleh Statistical Package Social Sciences (SPSS) v.26 for windows. Statistik deskriptif merupakan statistik yang menyampaikan refleksi data yang telah dihimpun menjadi sebuah informasi (Nurtantiono, 2020). Statistik inferensial di dalam percobaan hipotesis penelitian ini memanfaatkan alat analisis regresi linier berganda. Analisis tersebut meliputi pengujian kelayakan data yang diterapkan dengan menggunakan uji asumsi klasik.

Pengujian normalitas terhadap distribusi data dilangsungkan demi menilai apakah dalan bentuk regresi, variabel pengganggu punya distribusi yang normal. Salah satu uji normalitas yang digunakan ialah uji Kolmogorov-Smirnov. Data memiliki distribusi yang normal bila angka Asymp.Sig. (2-tailed) $\geq 0,05$ (Ghozali, 2018). Pengujian heteroskedastisitas ini difungsikan demi menilai apakah bentuk regresi timbul perbedaan variance per residual satu pengamatan ke pangamatan yang lainnya. Salah satu uji heteroskedastisitas yang digunakan ialah uji gletser. Adapun kriteria di dalam pengujian ini yaitu bila nilai Sig. $\geq 0,05$ sehingga dapat disimpulkan tidak timbul heteroskedastisitas. Lalu apabila nilai Sig. $<0,05$ bisa disimpulkan bahwa ada gejala heteroskedastisitas (Ghozali, 2018).

Pengujian multikolinieritas yang dilakukan di dalam penelitian ini bermaksud untuk menilai apakah bentuk regresi yang digunakan didapati adanya hubungan antara variabel bebas. 
Multikolinieritas bisa diamati melalui angka tolerance serta Variance Inflation Factor (VIF). Antara variabel bebas timbul masalah multikolinieritas bila angka VIF $\geq 10$ alias angka Tolerance $<0,10$ dan antar variabel tidak timbul masalah multikolinieritas, bila angka VIF $\geq 10$ alias angka Tolerance $<0,10$ (Ghozali, 2018).

Pengujian autokorelasi yang ditetapkan di dalam penelitian bermaksud untuk menilai apakah di dalam bentuk regresi linier ditemukan hubungan antara kesalahan pengganggu dalam tahun $\mathrm{t}$ serta kesalahan penganggangu di tahun t-1 (sebelumnya). Salah satu metode yang digunakan yaitu uji Durbin-Watson (DW test). Data timbul gejala autokorelasi positif bila nilai DW lebih kecil dari dI. Data tidak dapat disimpulkan apakah timbul gejala autokorelasi bila nilai DW ada diantara dI, du serta nilai DW ada diantara 4-dU serta 4-dI. Data tidak timbul autokorelasi apabila nilai DW ada diantara dU hingga 4-dU. Data timbul autokorelasi negatif jika nilai DW lebih besar dibandingkan 4-dI (Ghozali, 2018).

Pengujian linieritas difungsikan demi menilai apakah detail model yang signifikan sudah akurat ataupun belum. Adapun parameter dalam uji linieritas ini ialah, bila nilai Sig alias signifikan yang terdapat pada baris deviation from linearity $\geq 0,05$ lalu bisa ditarik kesimpulan koneksi antara variabel yaitu linier. Sebaliknya bila nilai Sig alias signifikan yang terdapat dalam deviation from linearity $\leq 0,05$ sehingga dapat disimpulkan koneksi antar variabel tidak linier (Ghozali, 2018).

Pengujian simultan berguna demi mengkonfirmasi apakah variabel bebas dan variabel terikat secara serempak mempunyai hubungan yang signifikan dengan tolok ukur apabila nilai Sig $<0,05$ hingga bisa ditarik kesimpulan bahwasanya variabel bebas mempunyai pengaruh secara serempak terhadap variabel terikat (Ghozali, 2018). Pengujian parsial difungsikan demi membuktikan betapa besar pengaruh variabel bebas secara singular dalam membuktikan perbedaan variabel terikat. Kriteria penilaian dalam uji parsial ini yaitu bilamana nilai Sig. $<0,05$ lalu bisa ditarik kesimpulan bahwasanya variabel bebas mempunyai pengaruh secara singular terhadap variabel terikat. Kebalikannya, bilamana nilai Sig. $>0,05$ bisa ditarik kesimpulan bahwasanya variabel bebas tidak memiliki pengaruh secara singular terhadap variabel terikat (Ghozali, 2018). Koefisien determinansi dalam penelitian difungsikan untuk memperkirakan betapa besar kecakapan model dalam menggambarkan variabel-variabel terikat dengan nilai adjusted $\mathrm{R}^{2}$ (Ghozali, 2018).

Model regresi linier berganda yang diterapkan di dalam penelitian ini yaitu:

$F D=\beta_{0}+\beta_{1} S M R+\beta_{2} R B C+\beta_{3} U K+\beta_{4} I N F+\beta_{5} N T+e$

Keterangan:

FD = financial distress yang dinilai menggunakan metode altman z-score,

$\beta 0=$ konstanta,

$\beta_{1} S M R=$ koefisien variabel solvency margin ratio,

$\beta_{2} R B C=$ koefisien variabel risk based capital,

$\beta_{3} S I Z=$ koefisiensi variabel ukuran perusahaan,

$\beta_{4} I N F=$ koefisiensi variabel inflasi,

$\beta_{5} K U R=$ koefisiensi variabel kurs,

$e \quad=$ error varians. 
Tabel 1. Deskripsi dan Pengukuran Variabel

\begin{tabular}{|c|c|c|}
\hline Variabel & Deskripsi & Pengukuran \\
\hline $\begin{array}{l}\text { Variabel Terikat } \\
\text { Financial Distress }\end{array}$ & $\begin{array}{l}\text { Keadaan dimana suatu perusahaan } \\
\text { sedang mengalami kesulitan keuangan } \\
\text { yang mana jika tidak ditanggapi secara } \\
\text { serius akan mengakibatkan } \\
\text { kebangkrutan. }\end{array}$ & $\begin{array}{c}\text { Altman Z-score Non-Manufaktur } \\
\mathrm{Z}=6,56 \mathrm{~T}^{1}+3,26 \mathrm{~T}^{2}+6,72 \mathrm{~T}^{3} \\
+1,05 \mathrm{~T}^{4}\end{array}$ \\
\hline $\begin{array}{l}\text { Variabel Bebas } \\
\text { Solvency Margin Ratio }\end{array}$ & $\begin{array}{l}\text { Rasio yang difungsikan untuk } \\
\text { mengungkap derajat kapabilitas } \\
\text { keuangan perusahaan ketika mengampu } \\
\text { risiko yang akan mengalami penutupan } \\
\text { di masa mendatang. }\end{array}$ & $\frac{\text { Modal Sendiri }}{\text { Premi Netto }} \times 100 \%$ \\
\hline Risk Based Capital & $\begin{array}{l}\text { Rasio yang difungsikan untuk menilai } \\
\text { tingkat kesehatan perusahaan asuransi. }\end{array}$ & $\frac{\text { Tingkat solvabilitas }}{\text { Batas tingkat solvabilitas minimum }} \times 100 \%$ \\
\hline Ukuran Perusahaan & $\begin{array}{l}\text { Total Aset yang dikuasai perusahaan } \\
\text { mencerminkan besarnya ukuran } \\
\text { perusahaan tersebut. }\end{array}$ & Ln total aset \\
\hline Inflasi & $\begin{array}{l}\text { Keadaan di mana harga-harga } \\
\text { mengalami kenaikan secara terus- } \\
\text { menerus. }\end{array}$ & $\begin{array}{c}\text { Rata-rata inflasi setiap tahun yang } \\
\text { ditemui pada hasil terbitan Bank } \\
\text { Indonesia periode } 2015-2019 \text {. }\end{array}$ \\
\hline Nilai Tukar & $\begin{array}{l}\text { Nilai pertukaran mata uang dari satu } \\
\text { negara ke mata uang negara lain. }\end{array}$ & $\frac{\text { Kurs Jual+Kurs Beli }}{2}$ \\
\hline
\end{tabular}

\section{HASIL DAN PEMBAHASAN}

Statistik deskriptif ialah analisis yang difungsikan demi mendiskripsikan mengenai distribusi frekuensi variabel-variabel di dalam penelitian (Ghozali, 2018). Analisis statistik deskriptif yang akan ditetapkan di dalam penelitian meliputi: jumlah sampel, nilai rata-rata, nilai terendah, nilai tertinggi serta standar deviasi. Kesimpulan dari analisis statistik deskriptif yang ditetapkan pada masing-masing variabel ditunjukan di dalam tabel berikut:

Tabel 2. Statistik Deskriptif

\begin{tabular}{cccccc}
\hline Variabel & Observasi & Minimum & Maximum & Mean & Std. Deviation \\
\hline FD & 35 & 0,37 & 11,49 & 3,3797 & 3,39646 \\
SMR & 35 & 0,41 & 5,78 & 1,6594 & 1,19437 \\
RBC & 35 & 0,00 & 5,57 & 2,2900 & 1,02393 \\
UK & 35 & 11,59 & 13,42 & 12,1414 & 0,45718 \\
INF & 35 & 0,03 & 0,06 & 0,0377 & 0,01031 \\
NT & 35 & 13473 & 14390 & 13757,54 & 301,126 \\
\hline
\end{tabular}

Tabel 1 menunjukan jumlah objek pengamatan $(\mathrm{N})$ di dalam penelitian ini sejumlah 35 perusahaan asuransi jiwa dan umum yang tercatat di BEI selama tahun 2015-2019. SMR mempunyai nilai paling rendah sejumlah 0,41 dan nilai paling tinggi sebesar 5,78 serta secara menyeluruh, variabel RBC memiliki nilai rata-rata 1,6594 serta standar deviasi 1,19437. RBC mempunyai nilai paling rendah sebesar 0,00 serta nilai paling tinggi sebesar 5,57 kemudian secara menyeluruh, variabel RBC memiliki angka rata-rata 2,2900 dan standar deviasi 1,02393. UK mempunyai angka paling rendah sejumlah 11,59 dan nilai paling tinggi sebesar 13,42 serta secara menyeluruh, variabel UK mempunyai nilai rata-rata 12,1414 serta standar deviasi 0,45718 . INF 
mempunyai angka paling rendah sebesar 0,03 serta nilai paling tinggi sebesar 0,06 serta secara menyeluruh, variabel INF mempunyai angka rata-rata sejumlah 0,0377 beserta standar deviasi sejumlah 0,01031 . NT mempunyai angka paling rendah sejumlah 13473 dan nilai paling tinggi sebesar 14390 serta secara menyeluruh, variabel NT memiliki nilai rata-rata 13757,54 dan standar deviasi 301,126. Kemudian, FD mempunyai nilai paling rendah sejumlah 0,37 serta nilai paling tinggi sejumlah 11,49 serta secara menyeluruh, variabel FD memiliki nilai rata-rata 3,3797 serta standar deviasi 3,39646.

Analisis statistik inferensial di dalam penelitian dimanfaatkan untuk mencoba hipotesis. Pengujian tersebut menggunakan regresi linier berganda yang terdiri dari pengujian kelayakan model dilakukan dengan memakai uji asumsi klasik. Uji asumsi klasik yang telah ditetapkan di dalam penelitian ini diantaranya: uji normalitas, uji heteroskedastisitas, uji multikolinieritas serta uji autokorelasi. Selanjutnya pengujian signifikansi keseluruhan variabel secara serentak menggunakan uji $\mathrm{F}$, pengujian signifikansi variabel secara individual menggunakan uji $\mathrm{T}$ dan untuk mengetahui ketepatan prediksi hasil analisis menggunakan koefisien determinan.

Pengujian normalitas terhadap distribusi data dilangsungkan demi menilai apakah dalan bentuk regresi, variabel pengganggu punya distribusi yang normal. Ada dua model untuk melangsungkan uji normalitas yakni dengan memakai analisis grafik serta analisis statistik (Ghozali, 2018). Uji Kolmogorov-Smirnov Test merupakan metode analisis statistik yang difungsikan di dalam penelitian ini.

Tabel 3. Hasil Uji Normalitas

\begin{tabular}{cccc}
\hline & $\mathbf{N}$ & $\begin{array}{c}\text { Asym Sig } \\
\text { (2-tailed) }\end{array}$ & Keputusan \\
\hline $\begin{array}{c}\text { Kolmogrov- } \\
\text { Smirnov Z }\end{array}$ & 35 & 0,200 & $\begin{array}{c}\text { Ditribusi } \\
\text { Normal }\end{array}$ \\
\hline
\end{tabular}

Kesimpulan uji normalitas yang memakai uji kolmogorov-smirnov yang tampak pada Tabel 2, maka disimpulkan data memiliki distribusi yang normal bila angka Asymp.Sig. (2-tailed) $\geq 0,05$. Tabel 2 menunjukan angka Asymp.Sig. (2-tailed) adalah 0,200 atau >0,05. Maka, dapat ditarik kesimpulan variabel solvency margin ratio, risk based capital, ukuran perusahaan, inflasi, nilai tukar dan financial distress mempunyai distribusi yang normal.

Pengujian multikolinieritas yang dilakukan di dalam penelitian ini bermaksud untuk menilai apakah bentuk regresi yang digunakan didapati adanya hubungan antara variabel bebas (Ghozali, 2018). Multikolinieritas bisa diamati melalui angka tolerance serta variance inflation factor (VIF). Antara variabel bebas timbul masalah multikolinieritas bila angka VIF $\geq 10$ alias angka Tolerance $<0,10$ dan antar variabel tidak timbul masalah multikolinieritas, bila angka VIF $\geq 10$ alias angka Tolerance $<0,10$.

Tabel 4. Hasil Uji Multikolinieritas

\begin{tabular}{|c|c|c|c|}
\hline \multicolumn{2}{|c|}{ Model } & $\begin{array}{l}\text { Collinierity } \\
\text { Tolerance }\end{array}$ & $\begin{array}{c}\text { Statistics } \\
\text { VIF }\end{array}$ \\
\hline \multirow[t]{5}{*}{1} & SMR & 0,407 & 2,459 \\
\hline & $\mathrm{RBC}$ & 0,935 & 1,069 \\
\hline & UK & 0,399 & 2,509 \\
\hline & INF & 0,887 & 1,128 \\
\hline & NT & 0,862 & 1,160 \\
\hline
\end{tabular}


Kesimpulan pengujian di Tabel 4 menunjukan bahwa pada variabel solvency margin ratio mempunyai angka tolerance 0,407 $\geq 0,10$ serta angka VIF 2,459 $<10$. Risk Based Capital mempunyai nilai tolerance sebanyak $0,935 \geq 0,10$ serta angka VIF $1,069<10$. Ukuran Perusahaan mempunyai angka tolerance sebanyak $0,399 \geq 0,10$ serta nilai VIF $2,509<10$. Inflasi mempunyai nilai tolerance sebanyak $0,887 \geq 0,10$ serta angka VIF $1,128<10$. Nilai tukar mempunyai angka tolerance sebesar $0,862 \geq 0,10$ serta nilai VIF $1,160<10$. Lalu dapat ditarik kesimpulan pengujian multikolinieritas pada bentuk regresi tak timbul gejala multikolinieritas antara variabel bebas yang dikarena nilai tolerance variabel solvency margin ratio, risk based capital, ukuran perusahaan, inflasi dan nilai tukar berada diatas 0,10 serta nilai VIF variabel solvency margin ratio, risk based capital, ukuran perusahaan, inflasi dan nilai tukar berada dibawah 10 .

Pengujian autokorelasi yang ditetapkan di dalam penelitian bermaksud untuk menilai apakah di dalam bentuk regresi linier ditemukan hubungan antara kesalahan pengganggu dalam tahun t serta kesalahan penganggangu di tahun t-1 (sebelumnya) (Ghozali, 2018). Terdapat banyak model untuk menemukan terdapat atau tidaknya gejala autokorelasi, salah satu metode tersebut yaitu uji Durbin-Watson (DW test). Data timbul gejala autokorelasi positif bila nilai DW lebih kecil dari dI. Data tidak dapat disimpulkan apakah timbul gejala autokorelasi bila nilai DW ada diantara dI, du serta nilai DW ada diantara 4-dU serta 4-dI. Data tidak timbul autokorelasi apabila nilai DW ada diantara dU hingga 4-dU. Data timbul autokorelasi negatif jika nilai DW lebih besar dibandingkan 4-dI.

Tabel 5. Hasil Uji Autokorelasi

\begin{tabular}{cccccc}
\hline DW & dL & dU & 4-dL & 4-dU & Kriteria \\
\hline 2,059 & 1,1601 & 1,8029 & 2,8399 & 2.1971 & dU < DW < 4-dU \\
\hline
\end{tabular}

Kesimpulan pengujian dalam Tabel 5 memperlihatkan bahwa nilai Durbin Watson sejumlah 2,059, sementara itu dalam Tabel 4, DW untuk " $\mathrm{k}$ " $=5$ (variabel bebas, tidak tergolong variabel terikat) serta nilai $\mathrm{N}=35$ besar nilai $\mathrm{dI}$ (batas bawah) $=1,1601$ serta $\mathrm{dU}$ (batas atas) = 1,8029 serta nilai 4-dl $=2,8399$ serta 4-dU $=2.1971$. Berlandaskan pada parameter yang ditetapkan di pedoman durbin-watson hingga diperoleh nilai sebagai berikut: $\mathrm{dU}<\mathrm{DW}<4$-dU alias 1,8029 $<2,059<2,8399$ yang artinya tidak timbul autokorelasi.

Pengujian heteroskedastisitas ini difungsikan demi menilai apakah bentuk regresi timbul perbedaan variance per residual satu pengamatan ke pangamatan yang lainnya (Ghozali, 2018). Ada banyak metode untuk menemukan terdapat atau tidak masalah heteroskedastisitas, uji glejser menjadi salah satu metode yang dipilih penulis untuk mengidentifikasi heteroskedastisitas. Uji glejser berikut dilaksanakan dengan metode meregres nilai absolut residual pada variabel bebas. Adapun kriteria di dalam pengujian ini yaitu bila nilai Sig. $\geq 0,05$ sehingga dapat disimpulkan tidak timbul heteroskedastisitas. Lalu apabila nilai Sig. $<0,05$ bisa disimpulkan bahwa ada gejala Heteroskedastisitas.

Tabel 6. Hasil Uji Heteroskedastisitas

\begin{tabular}{ccc}
\hline Model & Kriteria & Sig \\
\hline SMR & $>0,05$ & 0,845 \\
RBC & $>0,05$ & 0,077 \\
UK & $>0,05$ & 0,837 \\
INF & $>0,05$ & 0,542 \\
NT & $>0,05$ & 0,327 \\
\hline
\end{tabular}


Kesimpulan pengujian heteroskedastisitas yang terdapat di Tabel 6 membuktikan bahwa nilai Sig untuk variabel solvency margin ratio adalah sebanyak $0,845 \geq 0,05$, variabel risk based capital mempunyai nilai Sig $0,077 \geq 0,05$, variabel ukuran perusahaan mempunyai nilai Sig 0,837 $\geq 0,05$, variabel inflasi punya nilai Sig $0,542 \geq 0,05$, variabel nilai tukar mempunyai nilai Sig 0,327 $\geq 10$. Secara keseluruhan variabel bebas memperlihatkan nilai $\mathrm{Sig} \geq 0,05$, lalu berdasarkan hasil yang didapatkan dapat disimpulkan data penelitian terbebas dari masalah heteroskedastisitas.

Pengujian linieritas difungsikan demi menilai apakah detail model yang signifikan sudah akurat ataupun belum (Ghozali, 2018). Adapun parameter dalam uji linieritas ini ialah, bila nilai Sig alias signifikan yang terdapat pada baris deviation from linearity $\geq 0,05$ lalu bisa ditarik kesimpulan koneksi antara variabel yaitu linier. Sebaliknya bila nilai Sig alias signifikan yang terdapat dalam deviation from linearity $\leq 0,05$ sehingga dapat disimpulkan koneksi antar variabel tidak linier.

Tabel 7. Hasil Uji Linieritas

\begin{tabular}{ccc}
\hline Model & Kriteria & Sig \\
\hline SMR & $\geq 0,05$ & 0,610 \\
RBC & $\geq 0,05$ & 0,114 \\
UK & $\geq 0,05$ & 0,514 \\
INF & $\geq 0,05$ & 0,241 \\
NT & $\geq 0,05$ & 0,767 \\
\hline
\end{tabular}

Hasil uji linieritas pada Tabel 7 sampai Tabel 10 menunjukan nilai Sig alias Signifikan yang terdapat pada deviation from linierity sebesar $0,610 \geq 0,05$ bagi variabel solvency margin ratio, $0,114 \geq 0,05$ bagi variabel risk based capital, $0,514 \geq 0,05$ untuk variabel ukuran perusahaan, $0,241 \geq 0,05$ bagi variabel inflasi dan $0,767 \geq 0,05$ bagi variabel nilai tukar. Secara keseluruhan nilai Sig alias Signifikan yang terdapat dalam deviation from linierity $\geq 0,05$ lalu bisa dibuat kesimpulan bahwasanya signifikansi antar variabel yaitu linier.

Koefisien determinansi dalam penelitian difungsikan untuk memperkirakan betapa besar kecakapan model dalam menggambarkan variabel-variabel terikat dengan nilai adjusted $\mathrm{R}^{2}$ (Ghozali, 2018). Kesimpulan koefisien determinasi di dalam penelitian bisa diamati dalam tabel dibawah:

\begin{tabular}{ccc}
\begin{tabular}{c} 
Tabel 8. Hasil Uji Koefisien Determinasi \\
\hline Model
\end{tabular} & $\begin{array}{c}\mathbf{R} \\
\text { Square }\end{array}$ & $\begin{array}{c}\text { Adjusted R } \\
\text { Square }\end{array}$ \\
\hline 1 & 0,426 & 0,328 \\
\hline
\end{tabular}

Kesimpulan analisis data penelitian pada Tabel 8 memperlihatkan bahwa variabel financial distress yang tertera pada adjusted $\mathrm{R}^{2}$ sebanyak 0,328 alias 32,8\%. Kesimpulan tersebut menunjukan bahwa variabel bebas yaitu solvency margin ratio, risk based capital, ukuran perusahaan, inflasi dan nilai tukar mampu memaparkan variabel bebas sebanyak 32,8\%, kekurangan sebanyak $67,2 \%$ digambarkan variabel yang tidak dapat diperhitungkan di dalam analisis penelitian ini.

Pengujian simultan berguna demi mengkonfirmasi apakah variabel bebas dan variabel terikat secara serempak mempunyai hubungan yang signifikan dengan tolok ukur apabila nilai Sig 
$<0,05$ hingga bisa ditarik kesimpulan bahwasanya variabel bebas mempunyai pengaruh secara serempak terhadap variabel terikat (Ghozali, 2018).

Tabel 9. Hasil Uji F

\begin{tabular}{llll}
\hline Model & & F & Sig \\
\hline 1 & Regression & 4,313 & 0,005
\end{tabular}

Uji F pada Tabel 9 menghasilkan nilai Sig. sebanyak $0,005<0,05$, lalu bisa didapat kesimpulan bahwa variabel solvency margin ratio, risk based capital, ukuran perusahaan, inflasi dan nilai tukar secara bersama-sama atau simultan dapat dikatakan layak terhadap financial distress. Pengujian parsial difungsikan demi membuktikan betapa besar pengaruh variabel bebas secara singular dalam membuktikan perbedaan variabel terikat (Ghozali, 2018). Kriteria penilaian dalam uji parsial ini yaitu bilamana nilai Sig. < 0,05 lalu bisa ditarik kesimpulan bahwasanya variabel bebas mempunyai pengaruh secara singular terhadap variabel terikat. Kebalikannya, bilamana nilai Sig. > 0,05 lalu bisa ditarik kesimpulan bahwasanya variabel bebas tidak memiliki pengaruh secara singular terhadap variabel terikat.

Tabel 10. Hasil Uji Parsial

\begin{tabular}{|c|c|c|c|c|}
\hline & \multirow[t]{2}{*}{ Model } & \multicolumn{2}{|c|}{$\begin{array}{l}\text { Unstandardized } \\
\text { Coefficients }\end{array}$} & \multirow[t]{2}{*}{ Sig. } \\
\hline & & B & Std. Error & \\
\hline \multirow[t]{6}{*}{1} & (Constant) & $-97,899$ & 30,310 & 0,003 \\
\hline & SMR & $-1,893$ & 0,627 & 0,005 \\
\hline & $\mathrm{RBC}$ & 0,747 & 0,482 & 0,132 \\
\hline & UK & 5,463 & 1,655 & 0,003 \\
\hline & INF & 49,528 & 49,183 & 0,322 \\
\hline & NT & 0,003 & 0,002 & 0,153 \\
\hline
\end{tabular}

Dari Tabel 10, didapati hasil analisis regresi diperoleh nilai koefisien bagi variabel solvency margin ratio sebesar -1,893, variabel risk based capital sebesar 0,747 , variabel ukuran perusahaan sebesar 5,463, variabel inflasi sebesar 49,528 dan variabel nilai tukar sebesar 0,003 dengan konstanta $-97,899$. Sehingga persamaan regresi yang diperoleh yaitu:

$\mathrm{Y}=-97,899-1,893 \mathrm{SMR}+0,747 \mathrm{RBC}+5,463 \mathrm{UK}+49,528 \mathrm{INF}+0,003 \mathrm{NT}$.

Kesimpulan analisis regresi linier berganda pada Tabel 10, dengan memakai derajat signifikansi alpha sebanyak 0,05 dapat ditarik kesimpulan hasil uji hipotesis berikut: solvency margin ratio mempunyai pengaruh yang signifikan untuk memperkirakan situasi financial distress, hal tersebut ditandai dengan angka signifikan dibawah nilai alpha yaitu sebesar 0,005. Selanjutnya, kriteria regresi yang bertanda minus menunjukan variabel solvency margin ratio mempunyai pengaruh yang negatif terhadap situasi financial distress. Lalu, dapat ditarik kesimpulkan bahwa hipotesis H1 diterima. Hal ini dapat diartikan bahwa makin kecil rasio margin solvency maka makin besar probabilitas perusahaan tersebut menjumpai situasi financial distress. Batas solvabilitas yang rendah berarti perusahaan menghadapi risiko yang signifikan tinggi karena premi yang tinggi. Perlu analisa lebih lanjut untuk menentukan tingkat keparahan penutupan berlebih yang tidak sebanding dengan keuangan perusahaan, tingkat keparahan dan kemampuan keuangan perusahaan. Sesuatu yang harus dianalisis; kestabilan keuntungan underwriting perusahaan, distribusi premi, tingkat kecukupan proteksi reasuransi, distribusi dan perubahan nilai investasi (Ikatan Akuntan Indonesia, 1994). Kesimpulan ini selaras dengan kesimpulan 
penelitian yang dilaksanakan Zamachsyari \& Amanah (2016) yang mengungkapkan bahwa variabel solvency margin ratio ada pengaruh negatif terhadap financial distress.

Risk based capital tidak ada pengaruh terhadap financial distress. Hal tersebut terbukti bahwa angka signifikan diatas alpha yaitu sebesar 0,132 . Sehingga dapat disimpulkan hipotesis $\mathrm{H} 2$ ditolak. Dengan adanya peraturan batas minimum risk based capital sebesar $120 \%$ yang diatur oleh pemerintah melalui Keputusan Menteri Keuangan Nomor 53/PMK.010/2012 membuat perusahaan berusaha secara maksimal memenuhi batas minimum tersebut. Selain itu, menurut Nurfadila et al., (2015) terkadang pengukuran modal berbasis risiko yang memenuhi standar sering digunakan sebagai sarana promosi untuk menarik minat masyarakat dalam membeli polis, sehingga peluang untuk keberlangsungan usahanya tinggi dan menghindari dari keadaan financial distress. Kesimpulan di dalam penelitian ini tidak selaras pada penelitian yang telah dilangsungkan Dewi \& Mahfudz (2017) yang telah mengungkapkan bahwasanya risk based capital ada pengaruh terhadap financial distress.

Ukuran perusahaan mempunyai pengaruh pada keadaan financial distress. Hal tersebut terbukti bahwa angka signifikan dibawah alpha yaitu senilai 0,003. Maka dapat disimpulkan H3 diterima. Putra \& Badjra (2015) menyatakan bahwa ukuran perusahaan yang besar akan sebanding dengan pengeluaran dana untuk operasional perusahaan, sehingga profitabilitas yang dihasilkan perusahaan akan semakin menurun. Loman \& Male (2015) juga berpendapat bahwa semakin besar suatu perusahaan maka kecenderungan penggunaan dana eksternal juga akan semakin besar yang akan berujung pada potensi financial distress. Sehingga dapat ditarik kesimpulan bahwa makin besar ukuran perusahaan menunjukan bahwa makin besar pula tingkat probabilitas perusahaan menghadapi financial distress. Hasil yang didapat pada penelitian selaras pada penelitian yang telah dilangsungkan Rahmawati \& Khoiruddin (2017) yang telah mengungkapkan ukuran perusahaan ada pengaruh terhadap financial distress.

Inflasi tidak ada pengaruh pada keadaan financial distress. Hal ini teruji dengan angka signifikan diatas alpha yaitu sebanyak 0,322. Sehingga dapat disimpulkam H4 ditolak. Berlandaskan data yang diperoleh di dalam penelitian ini menunjukan jika tingkat inflasi di Indonesia pada tahun 2015-2019 cenderung dibawah 10\%. Hal tersebut menurut Nababan, Mangantar, \& Maramis (2019) jika inflasi disuatu negara lebih dari 10\%, maka hal tersebut akan berpengaruh terhadap risiko bisnis perusahaan. Sehingga dapat disimpulkan bahwa jika inflasi disutau negara tidak bergerak secara fluktuatif dan masih dibawah $10 \%$, maka tingkat probabilitas financial distress perusahaan asuransi yang beroperasi makin kecil. Akan tetapi, kesimpulan di dalam penelitian berbeda pada kesimpulan penelitian yang dilangsungkan oleh Ruhadi \& Mai (2017), Rohiman \& Damayanti (2019) yang menyampaikan bahwa tingkat inflasi mempunyai pengaruh pada situasi financial distress.

Nilai tukar tidak ada pengaruh pada situasi financial distress. Hal tersebut teruji dengan angka signifikan diatas alpha yakni sebesar 0,153. Sehingga dapat disimpulkan H5 ditolak. Putri (2015) menyampaikan bahwa nilai tukar tidak mempengaruhi terhadap naik turunya harga saham, hal tersebut berarti naik atau turunya nilai tukar tidak akan mempengaruhi laba yang dihasilkan dari aktivitas investasi perusahaan. Hal tersebut terjadi karena apabila perusahaan asuransi menjadikan return saham sebagai sumber pendapatan utama tentunya perusahaan akan memaksimalkan kemampuan dalam pengelolaan keuangan perusahaan, sehingga probabilitas financial distress akan semakin kecil. Sedangkan penelitian yang dilangsungkan oleh Rohiman \& 
Damayanti (2019) yang menyampaikan bahwa nilai tukar mempunyai pengaruh terhadap financial distress.

\section{SIMPULAN DAN REKOMENDASI}

Penelitian ini dilakukan demi membuktikan bahwa terdapat pengaruh kinerja keuangan, risk based capital, ukuran perusahaan serta makroekonomi terhadap situasi financial distress atas perusahaan asuransi jiwa serta umum yang tercatat di Bursa Efek Indonesia. Bersumber pada penelitian yang sudah dilaksanakan didapat sejumlah simpulan yaitu hanya variabel ukuran perusahaan yang berpengaruh terhadap situasi financial distress. Temuan di dalam penelitian ini diharapkan dapat membatu nasabah untuk memperkirakan bahwa ukuran perusahaan merupakan salah satu faktor yeng mendorong perusahaan asuransi mengalami kondisi financial distress sehingga para nasabah dapat memilih asuransi yang tepat demi proteksi di masa mendatang. Sedangkan untuk perusahaan, diharapkan dapat memberikan kontribusi informasi bahwa besarnya aset perusahaan merupakan aspek yang mendorong timbulnya financial distress, sehingga perusahaan dapat melakukan pengelolaan lebih baik agar perusahaan dapat berjalan dalam jarak waktu yang tidak terbatas.

Adapun keterbatasan dalam penelitian ini yaitu hanya perusahaan asuransi jiwa dan umum periode 2015-2019 yang terdaftar di Bursa Efek Indonesia yang hanya dijadikan sampel dalam penelitian ini, sehingga sampel cenderung lebih sedikit. Selanjutnya, banyaknya metode pengukuran financial distress dengan tingkat keakuratan yang berbeda-beda membuat penulis kesulitan menentukan metode yang akan digunakan. Peneliti berharap, penelitian berikutnya dapat memperbanyak jumlah sampel penelitian agar memberikan kesimpulan yang lebih maksimal seperti mengambil sampel dari perusahaan sektor perbankan yang dijadikan sebagai populasi. Selain itu, peneliti berikutnya dapat menggunakan variabel independen di luar rasio keuangan seperti, good corporete governance ataupun corporate social responsibility. Selanjutnya, penulis merekomendasikan agar penelitian berikutnya memakai ukuran yang lain untuk menentukan perusahaan mengalami financial distress misalnya model zmijewski ataupun springate.

\section{DAFTAR PUSTAKA}

Afif, M. N., \& Karmila, M. (2016). Analysis Financial Performance Based on Early Warning System in PT General Insurance Bumiputera Muda 1967. Jurnal Akunida, 2(2), 55-61. https://ojs.unida.ac.id/JAKD/article/view/1401

Ananta, Y. (2019). Pertumbuhan Industri Asuransi Lesu, Apa Penyebabnya? CNBC Indonesia.

Cinantya, I. G. A. A. P., \& Merkusiwati, N. K. L. A. (2015). Pengaruh Corporate Governance, Financial Indicators dan Ukuran Perusahaan pada Financial Distress. E-Jurnal Akuntansi Universitas Udayana, 10(3), 897-915.

Darmawan, S. (2017). Analisis Pengaruh Corporate Governance, Variabel Ekonomi Makro terhadap Financial Distress dengan Variabel Kontrol Ukuran Perusahaan dan Jenis Kepemilikan. Efektif Jurnal Ekonomi Dan Bisnis, 7(1), 100-122.

Dewi, T. T. C., \& Mahfudz. (2017). Effect Of Change in Surplus Ratio, Incurred Loss Ratio, Liquidity Ratio, Premium Growth Ratio, Size and Risk Based Capital to Predict The Possibilities Of Financial Distress: The Case of Indonesian Non-Life Insurance Listed in Indonesia Insurance Director. Advanced Science Letters, 23(8), 7285-7288. https://doi.org/10.1166/asl.2017.9352 
Fatkurrohmah, L., Sukarno, H., \& Farida, L. (2015). Analysis of Financial Performance Insurance Company Listed in Indonesian Stock Exchange. Manajemen Keuangan.

Fatmawati, A., \& Wahidahwati. (2017). Faktor-Faktor yang Mempengaruhi Financial Distress (Studi pada Perusahaan Manufaktur di BEI) Wahidahwati Sekolah Tinggi Ilmu Ekonomi Indonesia (STIESIA) Surabaya. Jurnal Ilmu dan Riset Akuntansi, 6, 1-17. https://docobook.com/faktor-faktor-yang-mempengaruhi-financial-distress.html

Ghozali, I. (2018). Aplikasi Analisis Multivariate dengan program IBM SPSS 25 (9 ed.). Badan Penerbit Universitas Diponegoro.

Ikatan Akuntan Indonesia. (1994). Pernyataan Standar Akuntansi Keuangan (PSAK). Jakarta: Salemba Empat.

Loman, R. K., \& Male, M. I. (2015). Determinan terhadap Prediksi Financial Distress pada Perusahaan Manufaktur di Bursa Efek Indonesia. Jurnal Riset Ekonomi dan Manajemen, 15(2), 371. https://doi.org/10.17970/jrem.15.1502013.id

Muatthoroh, S. (2019). Pengaruh Foreign Inflow, Inflasi, Suku Bunga dan Kurs terhadap Return Saham Perusahaan Sektor Asuransi yang Terdaftar di Bursa Efek Indonesia Tahun 20142018. In $A \gamma \alpha \eta, 8(5)$. Repository Universitas Pancasakti Tegal.

Nababan, M., Mangantar, M., \& Maramis, J. B. (2019). Dampak Inflasi, Suku Bunga, Struktur Modal terhadap Risiko Bisnis, Return Saham Asuransi di BEI. Jurnal EMBA: Jurnal Riset Ekonomi, Manajemen, Bisnis dan Akuntansi, 7(4), 4639-4650. https://doi.org/10.35794/emba.v7i4.25356

Nurfadila, S., Hidayat, R. R., \& Sulasmiyati, S. (2015). Analisis Rasio Keuangan dan Risk Based Capital untuk Menilai Kinerja Keuangan Perusahaan Asuransi. Jurnal Administrasi Bisnis (JAB), 22(1), 1-9.

Nurtantiono, A. (2020). Analisis Regresi Kasus dan Analisis dengan SPSS. Penerbit Sekolah Tinggi Ilmu Ekonomi Surakarta.

Primasari, N. S. (2018). Analisis Altman Z-Score, Grover Score, Springate, dan Zmijewski sebagai Signaling Financial Distress (Studi Empiris Industri Barang-Barang Konsumsi di Indonesia). Accounting and Management Journal, 1(1), 23-43. https://doi.org/10.33086/amj.v1i1.70

Priyatnasari, S., \& Hartono, U. (2019). Rasio Keuangan, Makroekonomi dan Financial Distress: Studi pada Perusahaan Perdagangan, Jasa dan Investasi di Indonesia. Jurnal Ilmu Manajemen, 7, 1-12.

Putra, A., \& Badjra, I. (2015). Pengaruh Leverage, Pertumbuhan Penjualan dan Ukuran Perusahaan terhadap Profitabilitas. E-Jurnal Manajemen Universitas Udayana, 4(7), 249411.

Putri, L. P. (2015). Pengaruh Inflasi dan Nilai Tukar Rupiah atas Dollar AS terhadap Kinerja Saham Perusahaan Property dan Real Estate di Indonesia. Ekonomikawan: Jurnal Ilmu Ekonomi dan Studi Pembangunan, 1-239.

Rachmatin, E., \& Negara, I. K. (2017). Prediksi Financial Distress Menggunakan Model Altman pada PerusahaanAsuransi yang terdaftar di Bursa Efek Indonesia. Jurnal Magister Manajemen Universitas Mataram, 6(1), 1-16.

Rahmawati, D., \& Khoiruddin, M. (2017). Pengaruh Corporate Governance dan Kinerja Keuangan dalam Memprediksi Kondisi Financial Distress. Management Analysis Journal, 6(1), 1-12.

Ramadhani, A. S., \& Lukviarman, N. (2009). Perbandingan Analisis Prediksi Kebangkrutan Menggunakan Model Altman Pertama, Altman Revisi, dan Altman Modifikasi dengan Ukuran dan Umur Perusahaan Sebagai Variabel Penjelas. Jurnal Siasat Bisnis, 13(1), 15-28. 
Rohiman, S. F., \& Damayanti, C. R. (2019). Pengaruh Inflasi, Nilai Tukar dan Suku Bunga terhadap Financial Distress. Jurnal Administrasi Bisnis, 72(2), 186-195.

Ruhadi, R., \& Mai, M. U. (2017). Bankruptcy Model Analysis: Comparative Studies Between Sharia and Non Sharia Manufacturing Companies. Al-Iqtishad: Journal of Islamic Economics, 9(2), 311-330. https://doi.org/10.15408/aiq.v9i2.4466

Sepang, V. V., Johnson, P. S., \& Sihombing, S. (2015). Pengaruh Pertumbuhan Laba dan Inflasi terhadap Harga Saham Perusahaan Asuransi di Bursa Efek Indonesia Tahun 2009-2013. Jurnal Ilmiah Buletin Ekonomi, 19(2), 59-69.

Subramanyam, K. (2017). Analisis Laporan Keuangan (11 ed.). Salemba Empat.

Trivena, S., Wijayanti, R., \& Budiarti, L. (2020). Analisis Penyebab Financial Distress yang Dialami oleh PT. Asuransi Jiwasraya (Persero). Akuntansi, Manajemen, dan Keuangan. https://prosiding.polinema.ac.id/sngbs/index.php/snamk/article/view/282

Utami, E. P., \& Khoiruddin, M. (2016). Pengaruh Rasio Keuangan Early Warning System terhadap Tingkat Solvabilitas Perusahaan Asuransi Jiwa Syariah Periode 2010-2013. Management Analysis Journal, 5(1), 55-62. https://doi.org/10.15294/maj.v5i1.8133

Wiguna, A., \& Susilawati, D. (2020). Analisis Ews dan Rbc untuk Menilai Kinerja Keuangan PT. Asuransi Takaful Keluarga Periode 2016-2018. Kinerja, 17(1), 105-112.

Zamachsyari, A. Z., \& Amanah, L. (2016). Pengaruh Kinerja Keuangan dan Ukuran Perusahaan terhadap Financial Distress. Pendidikan Ekonomi, 5(11), 1-15. 